\title{
Oribatid Mites of the Genus Epilohmannia (Acari: Oribatida: Epi- lohmanniidae) from Japan and Mongolia
}

\author{
BADAMDORJ BAYARTOGTOKH
}

Department of Soil Zoology, Institute of Environmental Science and Technology, Yokohama National University, Yokohama 240-8501, Japan and permanent address: Department of Zoology, Faculty of Biology, National University of Mongolia, Ulaanbaatar 210646, Mongolia

\begin{abstract}
Two known species of the oribatid mite genus Epilohmannia, E. cylindrica (Berlese) and E. spathulata Aoki, are redescribed. E. cylindrica is recorded for the first time from Mongolia. Two new species, Epilohmannia spathuloides sp. nov. and Epilohmannia shtanchaevae sp. nov. are described from larch litter in Yamanashi Prefecture (Mt. Yatsugatake), Central Japan and from deep soil in the mountain-steppe landscape of Central Mongolia, respectively. A key to the Japanese and Mongolian species of Epilohmanniidae is given.
\end{abstract}

Key words: Oribatida, Epilohmanniidae, new species, Japan, Mongolia

\section{Introduction}

The primitive oribatid mite superfamily Epilohmannioidea Oudemans, 1923 is monotypical and is based on the family Epilohmanniidae Oudemans, 1923. Epilohmanniidae is a relatively small family, but its classification is somewhat difficult. The family consists of only three genera, Epilohmannia Berlese, 1916, Epilohmannoides Jacot, 1936 and Neoepilohmannia McDaniel and Bolen, 1989. However, in a recent classification of oribatid mite genera, Balogh and Balogh (1992) have not included the last genus in Epilohmanniidae.

The genera Epilohmannoides and Neoepilohmannia are relatively small, and the former genus consisted of only four species (E. terrae Jacot, E. jacoti Norton, Metz \& Sharma, E. esulcatus Ohkubo and E. wallworki Hammer). Bolen and McDaniel (1989) included four species in Neoepilohmannia (N. multisetosa (Hammer), N. neotricha (Wallwork), N. ovata (Aoki) and N. taeda Bolen $\&$ McDaniel). More recently, Shtanchaeva (1996) transferred eight more species to this genus: $N$. ovalis (Berlese), N. guarani (Balogh \& Mahunka), N. lenkoi (Balogh \& Mahunka), N. maurii (Fernandez), N. rabori (Corpuz-Raros), N. xena (Mahunka), N. dolosa (Pérez-Iñigo \& Baggio) and $N$. zwarti (Hammen). Representatives of Epilohmannoides are known only from Palaearctic, Nearctic and Oriental regions. Members of Neoepilohmannia occur in Holarctic, Neotropical, Oriental and Ethiopian regions, but most species of both the genera are known only from type localities or have a restricted distribution.

The type genus, Epilohmannia is the largest in the family. According to Shtanchaeva (1996) there are 33 species or subspecies. However, I noted 30 nominal species and 9 subspecies belonging to this genus. The genus is distributed throughout the world, and some species exhibit a wide range of morphological variability. 
There are very few diagnostic characters, which distinguish different species of Epilohmannia. When original descriptions or redescriptions and illustrations of species are incomplete, it is almost impossible to distinguish between two or more species, which causes taxonomic confusion or misidentification of some closely related species. To avoid this problem, it is necessary to redescribe those species whose character states are unknown or poorly described and illustrated.

Detailed description and redescription of two Epilohmannoides species and supraspecific diagnoses of Epilohmanniidae by Norton et al. (1978) present useful information on the morphology of this group of mites.

This study focuses on the Mongolian and Japanese species of Epilohmannia. Representatives of the three epilohmanniid genera are distributed in Japan (Aoki 1961, 1965, 1970; Ohkubo 1979), but in Mongolia I have found only two species of Epilohmannia, one a new record for Mongolia, the second a species as new to science. Two known species, E. cylindrica (Berlese) and E. spathulata Aoki, redescribed here, are easily recognizable, but I include more detailed characterization and complete illustrations. The original descriptions of three other Japanese species, Neoepilohmannia ovata (Aoki), Epilohmannia pallida pacifica Aoki and Epilohmannoides esulcatus Ohkubo do not require redescription, but are included in the identification key, which is given at the end of the discussion.

\section{Materials and methods}

The Mongolian species studied here were collected between 1991 and 1996, from the mineral soils of mountain-steppe and sandy deserts in central and southern parts of the country, respectively. The Japanese species, E. spathuloides sp. nov. was collected in 1999, from litter of larch forest in central part of the country. The type locality and habitat characterization for each species are given in the "material examined" section. The redescription of another Japanese species, E. spathulata Aoki, is based on the type material, which was deposited in the National Science Museum, Tokyo. Immature stages are unknown for most of these species, except only the larval stage of E. cylindrica studied by Grandjean (1946).

The specific terminology used in this paper is based on that developed by Norton et al. (1978). All measurements are given in micrometers $(\mu \mathrm{m})$ and the average measurement value is given in brackets after the range.

\section{Descriptions of species}

\section{Epilohmannia cylindrica (Berlese) (Figs. 1-15)}

Lohmannia cylindrica Berlese, 1904, p. 22, pl. 2, fig. 40.

Epilohmannia cylindrica: Berlese, 1916, p. 176; Lombardini, 1936, p. 40; Balogh, 1943, p. 16, figs. 6 \& 9; Grandjean, 1946, p. 64, figs. 1 \& 2; Hammen, 1959, p. 53; Schuster, 1960, p. 198, fig. 1; Wallwork, 1964, p. 354, figs. 1 \& 2; Aoki, 1965, p. 309, figs. 1-3; Bulanova-Zachvatkina, 1967, p. 122; 1975, p. 71; PérezIñigo, 1968, p. 214, figs. 30-32; Bayoumi and Mahunka, 1976, p. 6, figs. 1-5; Balogh and Mahunka, 1983, p. 133, pl. 67, figs. a-e; Shtanchaeva and Koshanova, 1987, p. 30; Ayyildiz and Özkan, 1988, p. 122, figs. 7 \& 8; Shtanchaeva, 1996, p. 525, fig. 4.

Lesseria szanisloi Oudemans, 1917, p. 79, figs. 127-139; Schuster, 1960, p. 202, figs. 4 \& 5.

Epilohmannia verrucosa Jacot, 1934, p. 6, pl. 1, figs. 1-6; Aoki, 1965, p. 309. 


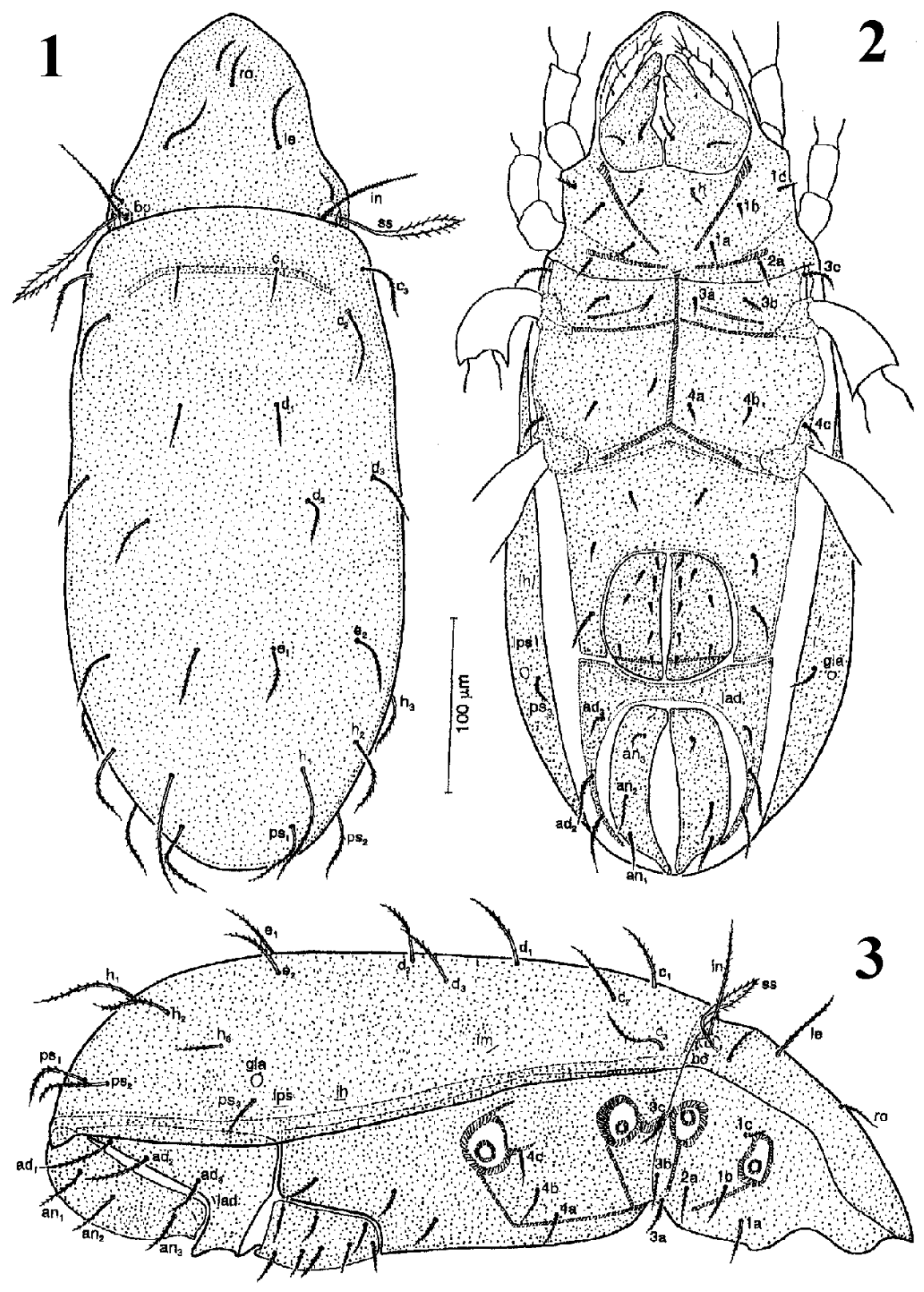

FIGURES 1-3. Epilohmannia cylindrica (Berlese, 1904). 1, dorsal aspect; 2, ventral aspect; 3, lateral aspect.

Measurements. Body length 484.0-550.8 (516.1) $\mu \mathrm{m}$; width of hysterosoma 183.6-214.2 (197.2) $\mu \mathrm{m}$; length of proterosoma 158.1-193.8 (176.5) $\mu \mathrm{m}$; width of proterosoma 127.5-137.7 (134.3) $\mu \mathrm{m}$; length of hysterosoma 336.6-372.3 (354.9) $\mu \mathrm{m}$.

Integument. Colour reddish-brown except rostrum and legs yellowish brown. Cerotegument very thick, dorsal and ventral plates as well as surface of legs densely covered by fine granules.

Prodorsum. Roughly elongate triangular in shape. In contracted specimens proterosoma partly retracted within hysterosoma (Fig. 1), but in most specimens proterosoma well separated from the 2000 
hysterosoma by broad sejugal articulation (Fig. 10). In dorsal view anterior margin of rostrum rounded, but in lateral aspect rostrum slightly projecting. Rostral setae (ro) relatively short, 20.8-24.7 (23.1) $\mu \mathrm{m}$, situated close to each other, conspicuously barbed. Relative position of rostral setae somewhat variable; their insertions usually situated obliquely i.e. left seta inserted slightly anterior to the right, but in some specimens two setae inserted at same level. Lamellar setae (le) rather long, 31.2-44.2 (37.4) $\mu \mathrm{m}$, conspicuously barbed bilaterally; distance between bases of pair longer than setal length. Interlamellar setae (in) long, 62.4-72.8 (66.3) $\mu \mathrm{m}$, distinctly barbed, situated close to respective bothridium (Fig. 4). Anterior exobothridial setae (exa) short, 18.2-26.0 (22.1) $\mu \mathrm{m}$, but well visible; posterior exobothridial setae (exp) very short, 9.8-10.4 (10.1) $\mu \mathrm{m}$, and thin, situated posterolateral to each bothridium. In some specimens seta $\exp$ concealed by anterior margin of notogaster, when proterosoma strongly retracted within hysterosoma. Sensillus ( ss) with rather long, smooth stalk and fusiform head bearing distinct barbs, about 67.2-101.4 (77.3) $\mu \mathrm{m}$ in length. Bothridia (bo) small, nearly cup-shaped, opening directed posterolaterally (Figs. 1, 4 \& 10).

Notogaster. Elongate oval, its anterior margin slightly arched or almost straight, and posterior margin broadly rounded. Relatively robust in lateral view, dorso-ventral thickness of hysterosoma in postgenital transects 130-156 (143) $\mu \mathrm{m}$. Distal half of each notogastral seta conspicuously barbed; seta $h_{1}$ longest, about twice as long as $e_{1}$, seta $p s_{3}$ shortest. Latero-opistosomal gland opening ( $\mathrm{gla}$ ) rather large, situated close to setae $p s_{3}$. Lyrifissures, im, ih and ips developed, visible in lateral aspect; other lyrifissures not descirnable (Figs. 1, $3 \&$ 10).

Gnathosoma. Subcapitulum with three pairs of barbed setae. Chelicera robust, with sclerotized teeth; seta cha shorter and thinner than $c h b$. Palp structure and setation similar to that of E. spathulata (see below), but trochanter inconspicuous.

Epimeral region. Apodemes apo.1, apo.2, apo.3 and apo.4 well developed. Epimeral regions between apo. 2 and apo. 4 divided by a sternal apodeme. Apodemes apo. 1 convergent, V-shaped, but not fused medially and widely separated from each other. Apodemes apo. 2 long, but well separated from each other; apo. 3 and apo. 4 completely fused medially. A pair of relatively short, but distinct ridges present anterior and parallel to apodemes apo.3. Epimeral setae medium long, subequal in length, distinctly barbed (Figs. 2 \& 11). Epimeral setal formula: 3-1-3-3. Discidium conspicuously developed, but relatively short. Acetabula I and II situated close to each other (Fig. 3).

Ano-genital region. Genital and anal apertures broadly oval in shape, the latter slightly larger than the former. Each genital plate with five setae along its median margin and three setae inserted laterally. Three pairs of aggenital setae with $a_{3}$ the longest. All genital and aggenital setae distinctly barbed. Anal setae slightly longer than genital setae. Anal lyrifissures ian located near the anteromedian corner of each anal plate, and obliquely oriented with respect to the body axis. Adanal setae distinctly barbed, $a d_{1}$ and $a d_{2}$ longer than $a d_{3}$. Adanal lyrifissures iad with similar shape as ian, situated adjacent to the anterolateral margin of anal aperture (Figs. 2, 11-13). Adanal plate narrowing posteriorly around anal aperture and incomplete posterior to anal region (Fig. 3).

Legs. Claws strongly thickened, with few serrations on the dorsal surface. Dorsodistal part of tarsi I and II with distinct projections; trochanters III and IV with a strong ventrodistal and a weak dorsodistal projections. Genua II and III with oblique striations. Tarsi I and II thicker, but shorter than tarsi III and IV; tibiae and genua III and IV more slender than tibiae and genua I and II. Femur and trochanter IV much longer than those of other legs. Formula of leg setation, trochanter to tarsus (including famulus): I (1-4-4-4-15); II (1-4-4-5-11); III (2-3-3-3-10); IV (2-3-3-3-9); formula of solenidia, genu to tarsus: I (2-1-3); II (1-1-2); III (1-1-0); IV (1-1-0). Solenidion $\omega_{1}$ of tarsus I curved, shorter than $\omega_{2} ; \omega_{3}$ short and thin. Famulus $\varepsilon$ very small, situated between solenidia $\omega_{1}$ and $\omega_{2}$. Solenidion $\sigma$ of genu I nearly as long as $\varphi$ of tibia I; $\sigma$ 'about twice shorter and thinner than $\sigma$. Setation of legs I-IV as shown in Figs. 5-9, 14 \& 15. 


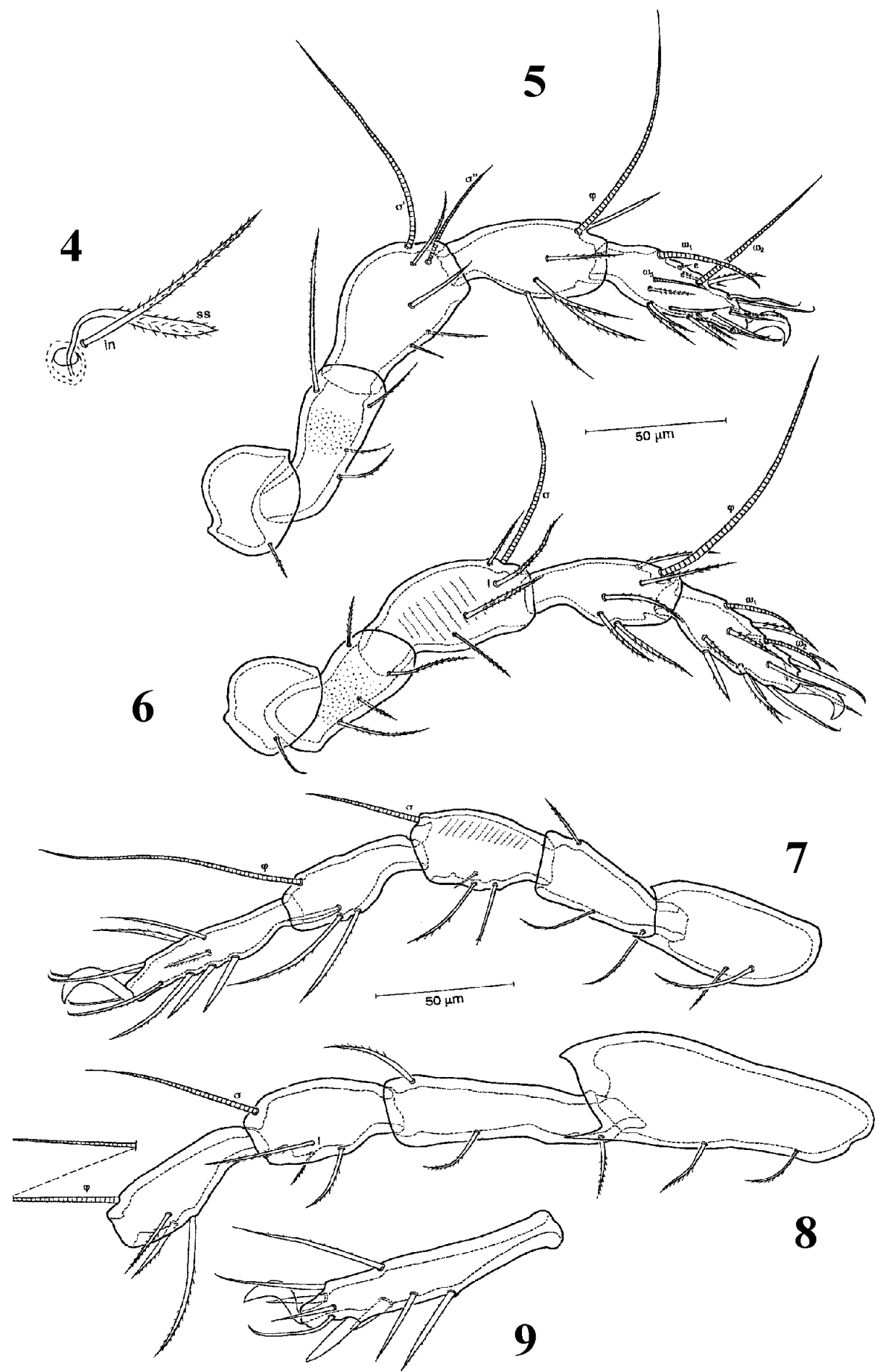

FIGURES 4-9. Epilohmannia cylindrica (Berlese, 1904). 4, sensillus, bothridium and interlamellar seta (in lateral view); 5, leg I (right, antiaxial aspect); 6, leg II (right, antiaxial aspect); 7, leg III (right, paraxial aspect); 8, trochanter, femur, genu and tibia IV (right, paraxial aspect); 9, tarsus IV (right, paraxial aspect). 


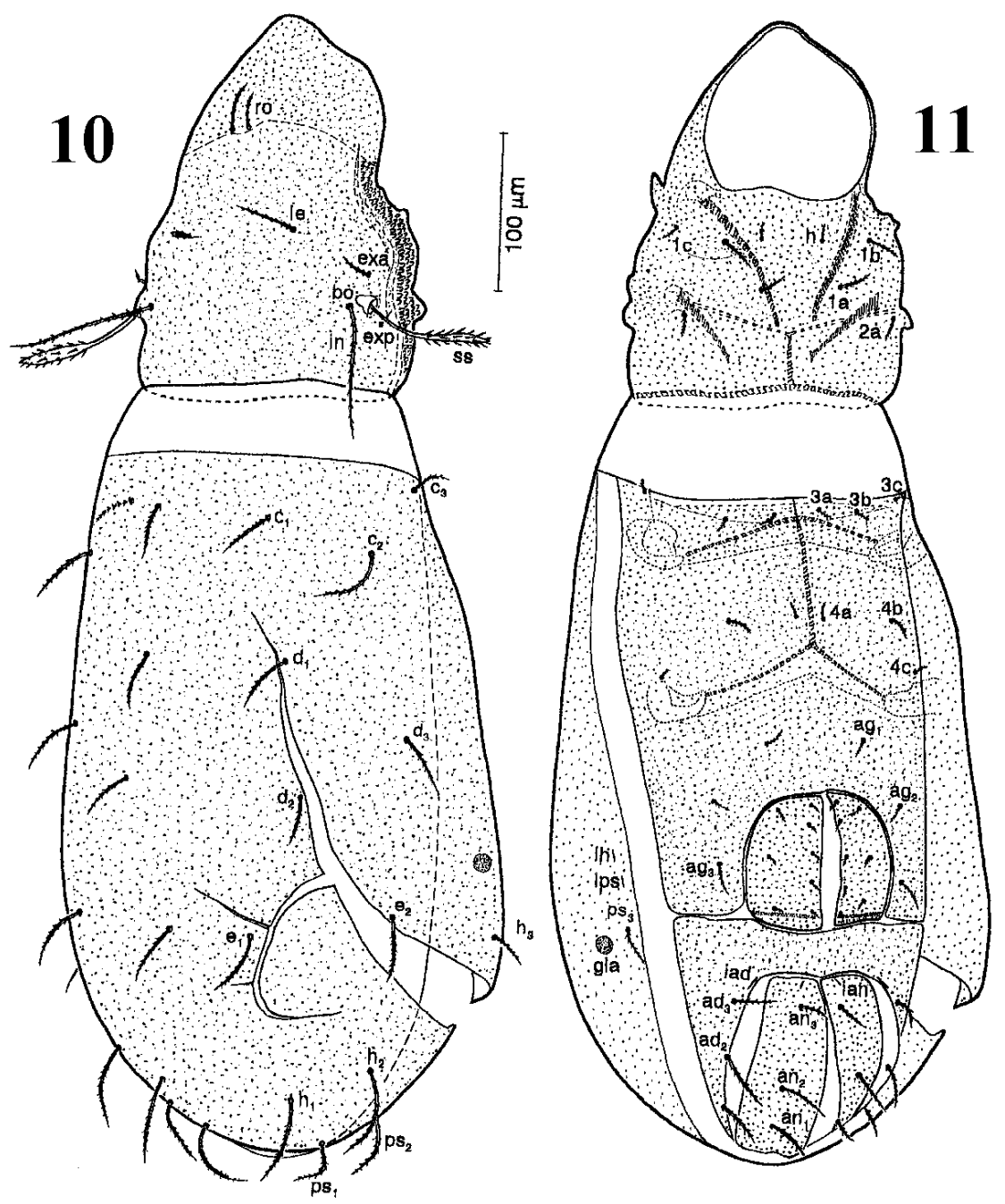

FIGURES 10-11. Epilohmannia cylindrica (Berlese, 1904), variable form. 10, dorsal aspect; 11, ventral aspect.

Variations. In the five studied specimens the following variations of morphological characters were noted. Arrangement of rostral setae was somewhat variable as shown in Figs. $1 \& 10$. Notogastral lyrifissures ih and ip usually lie relatively close to each other, but in some specimens, or on one side of a specimen $i h$ and $i p$ are widely separated from each other. Lyrifissure $i m$ was observed only in one specimen (Figs. 2, $3 \& 11$ ). The structure of genital region and shape of setae $u$ ' and $t c$ ' of tarsus IV were variable, as shown in Figs. 12-15.

Material examined. Four specimens (females): from sandy soil, Mt. Gurvan Saikhan, Mouth Yolyn Am, District Bayandalai, South Gobi Province, Mongolia, sandy desert, (Juniferus sabina +

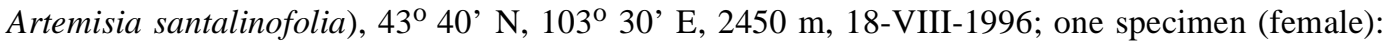
from sandy soil, Oasis Ehiin Gol, District Shinejinst, Bayankhongor Province, Mongolia, sandy desert (Haloxylon ammodendron + Tamarix sp.), 43ㄷ 55’ N, $98^{\circ}$ 45’ E, 1210 m, 21-VIII-1991, Leg. B. Bayartogtokh. 


\section{2}
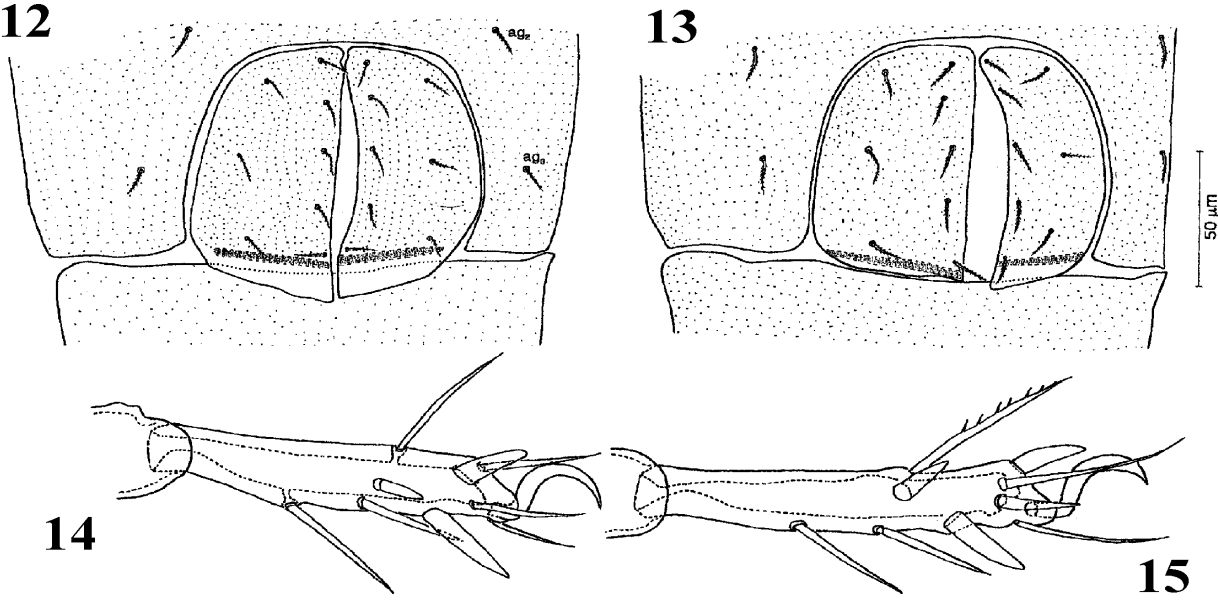

13

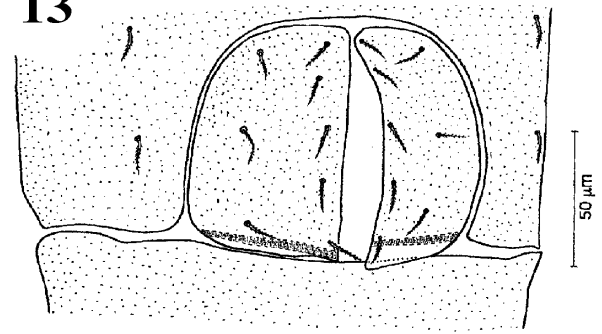

15

FIGURES 12-15. Epilohmannia cylindrica (Berlese, 1904), variable form. 12-13, genital region (variation), showing different development of the transverse ridges on genital plates; 14-15, tarsi IV, showing different structure of setae $a, s, t c$ and $u$.

Remarks. Character states of the Mongolian specimens of E. cylindrica agree well with those given in the original description by Berlese (1904) and redescriptions by Oudemans (1917), Wallwork (1964), Aoki (1965), Pérez-Iñigo (1968) and Bayoumi and Mahunka (1976). The Tchad and Spanish specimens of this species discussed by Wallwork (1964) and Pérez-Iñigo (1968) are slightly different from Mongolian material in several aspects. The sensilli of these are distinctly swollen or clavate, as opposed to lanceolate in Mongolian specimens. In Tchad and Spanish specimens the right rostral seta is inserted a little anterior to the left one, while the left seta is situated anterior than the right seta in Mongolian specimens. Wallwork (1964) mentioned that tarsus IV of Tchad specimens bears 4 swollen setae ( $p v^{\prime}, p v^{\prime}, a^{\prime \prime}$ and $s$ ), whereas setae $p v^{\prime}$ and $p v^{\prime}$ of Mongolian specimens are normally developed. Pérez-Iñigo (1968) showed four swollen setae ( $a^{\prime}, p v^{\prime \prime}, s$ and $\left.t c^{\prime}\right)$ on tarsus IV of Spanish specimens, more similar to those of one of Mongolian specimens (Fig. 15), but seta $p v$ " and $u$ ' of the Spanish form are slightly thicker and thinner, respectively, than those of the Mongolian form. Wallwork (1964) showed only six pairs of genital setae, but possibly some genital setae were lost or the single specimen examined by him was unusual. In their redescription based on Hungarian and Egyptian material, Bayoumi and Mahunka (1976) stated that tarsus IV has only two "thorn-like" setae ( $s$ and $a$ "), but their figure 3 shows seta $p v$ " which is nearly as thick as seta $s$. Also these authors illustrated 15 setae in lateral view, which was a drawing error (Norton et al. 1978).

Distribution. Palaearctic region (Berlese 1904; Oudemans 1917; Balogh 1943; Hammen 1959; Schuster 1960; Bulanova-Zachvatkina 1967, 1975; Pérez- Iñigo 1968; Bayoumi \& Mahunka 1976; Balogh \& Mahunka 1983; Karppinen et al. 1986, 1987, 1992; Shtanchaeva \& Koshanova 1987; Ayyildiz \& Özkan 1988; Krivolutsky 1995; Shtanchaeva 1996; Niedbala \& Olszanowski, 1997), and Mongolia (see "material examined" section); Nearctic region (Jacot 1934; Marshall et al. 1987; Behan-Pelletier 1993; Swift \& Norton 1998); Oriental region (Sheals 1965; Prasad 1974; Bhaduri \& Raychaudhuri 1981); Ethiopian region (Wallwork 1964); Oceania region (Aoki 1965; Schatz 1998). 
Epilohmannia spathulata Aoki (Figs. 16-22)

Epilohmannia spathulata Aoki, 1970, p. 399, figs. 5-8.

Epilohmannia spathulata: Fujikawa, 1972, p. 135, fig. 9.

I have examined the holotype and two paratype specimens mounted on slides (deposited in the collection of National Science Museum, Tokyo, No NSMT-Ac-164-166). All three specimens were slightly damaged. The original description of this species is very good, and gives sufficient information on most character states. However, complete illustrations of dorsal and lateral views and setation of legs other than tarsus IV given here, were not included in the original description.

Measurements. The type specimens were damaged, thus measurements of body size were impossible, but length measurements of some setae are given below in the appropriate sections.

Integument. colour of body light yellowish to yellowish brown. Cerotegument thin, posterior part of prodorsum with fine punctures; the anterior region of prodorsum as well as whole dorsal surface of notogaster and ventral plate lacking in punctation. Lateral part of podosoma smooth.

Prodorsum. Proterosoma retracted within hysterosoma. Anterior margin of rostrum rounded in both dorsal and lateral views. Rostral setae ( $r o$ ) short, 26-33 (29.5) $\mu \mathrm{m}$, thin, finely barbed, not reaching to tip of rostrum, positioned asymmetrically. Lamellar setae (le) longer than rostral setae, 43-55 (49.3) $\mu \mathrm{m}$, finely barbed bilaterally. Distance between bases of setae le-le about $1.5 \mathrm{x}$ setal length. Interlamellar setae (in) very long, 106-121 (113.8) $\mu \mathrm{m}$, weakly barbed bilaterally, situated medial to each bothridium. Anterior exobothridial setae (exa) smooth, 25-30 (27.5) $\mu \mathrm{m}$, nearly as long as rostral setae; posterior exobothridial setae (exp) 9-12 (11.5) $\mu \mathrm{m}$, less than half length exa. Sensillus (ss) long, 82-98 (90.5) $\mu \mathrm{m}$, with long, smooth stalk, and narrow fusiform head bearing distinct barbs. Bothridium (bo) small. (Fig. 16).
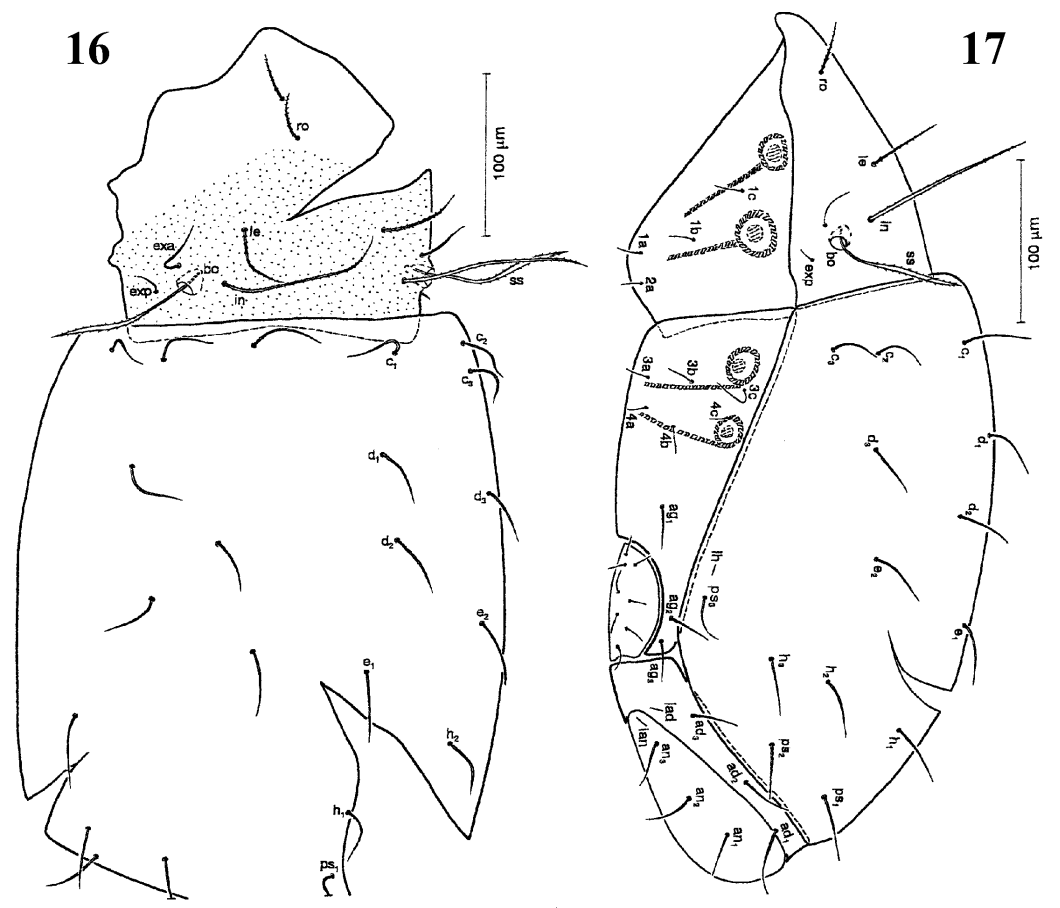

FIGURES 16-17. Epilohmannia spathulata Aoki, 1970. 16, dorsal aspect (posterior part of notogaster incomplete); 17, lateral aspect. 


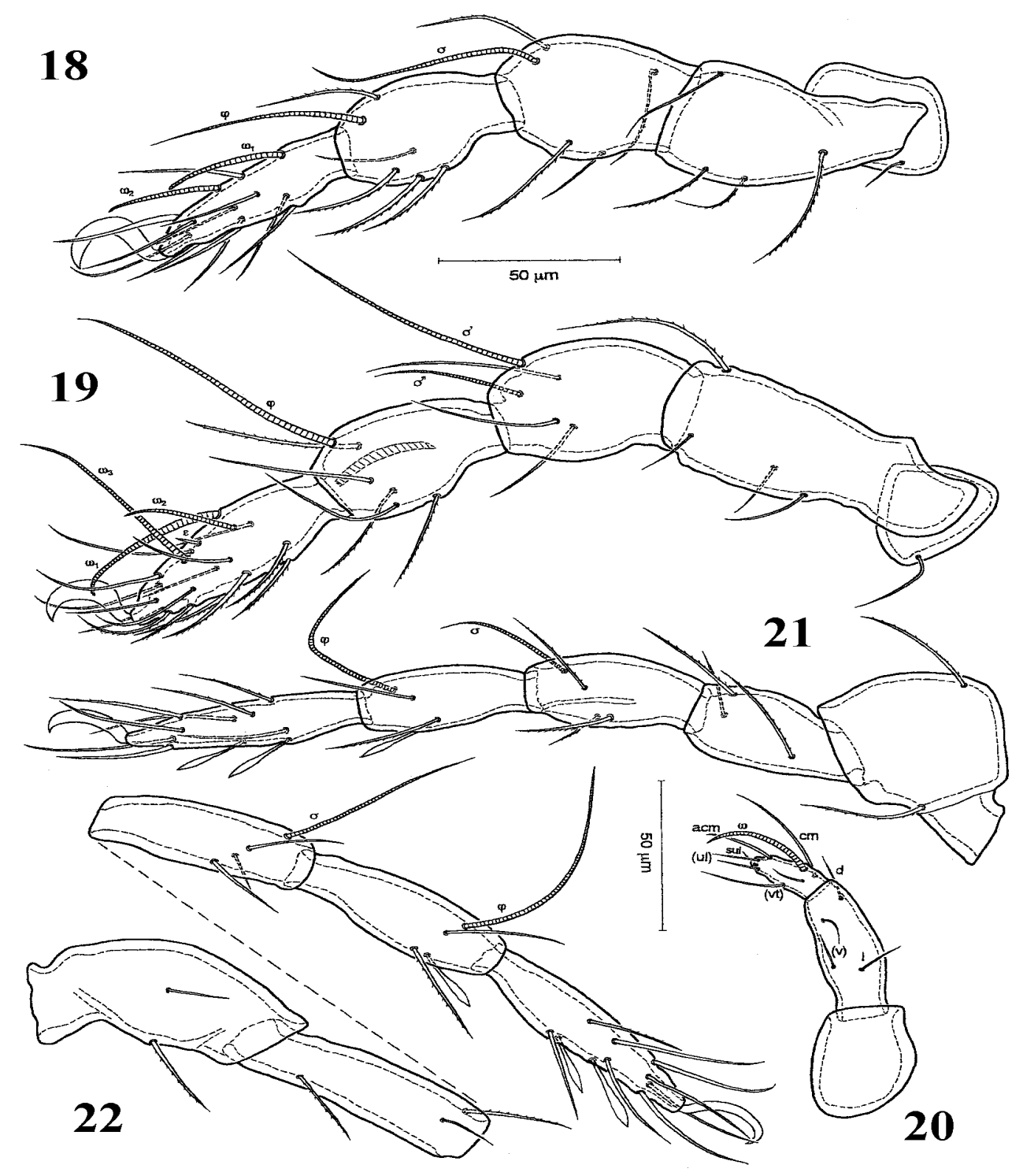

FIGURES 18-22. Epilohmannia spathulata Aoki, 1970. 18, leg II (left, antiaxial aspect); 19, leg I (left, antiaxial aspect); 20, palp (left, antiaxial); 21, leg III (right, paraxial aspect); 22, leg IV (left, paraxial aspect).

Notogaster. Notogastral setae thin, smooth, approximately subequal in length to one another, 38-46 (43.0) $\mu \mathrm{m}$. Latero-opistosomal gland opening gla inconspicuous. Only lyrifissure $i h$ evident (Figs. 16 \& 17). General aspect of lateral view similar to that of E. cylindrica (specimen showed in Fig. 17 was slightly flattened bilaterally).

Gnathosoma. Three pairs of smooth, but long hypostomal setae. Chelicerae robust, digits with four blunt teeth. Seta cha minute, chb long, thick. Palp three segmented, trochanter very large, without seta. Femur, genu and tibia fused together, with four smooth setae. Tarsus with a very thick solenidion $\omega$ and six setae; sul shortest and thinnest eupathidium (Fig. 20). 
Epimeral region. Structure of epimeral and ano-genital regions as in the original description. Epimeral ridges and apodemes apo.1, apo.2, apo.3 and apo.4 well developed. Epimeral setae short, 9-12 (11) $\mu \mathrm{m}$, thin, smooth (Fig. 17). Discidium inconspicuous.

Ano-genital region. Genital aperture oval, anal aperture narrowed anteriorly and strongly widened posteriorly, the latter aperture much larger than the former. Each genital plate with five setae along its median margin and three setae inserted laterally, 5-7 (6.2) $\mu \mathrm{m}$ in length. Aggenital setae thin, smooth, 11-14 (12.5) $\mu \mathrm{m}$, conspicuously longer than genital setae. All genital and aggenital setae smooth. Anal setae long, smooth, 11-15 (13) $\mu \mathrm{m}$. Anal lyrifissures ian located midway between median and lateral margins of each anal plate, and obliquely oriented with respect to the body axis. Adanal setae long, smooth, 11-16 (13.5) $\mu \mathrm{m}$ in length. Adanal lyrifissures iad situated almost transversely adjacent to the anterolateral margin of anal aperture (Fig. 17).

Legs. Claws strongly thickened, claws of tarsi I and II more stronger than those of tarsi III and IV. Tarsi I and II slightly thicker than those of the legs III and IV; tibiae, genua and femora I and II much thicker than those of the legs III and IV. Formula of leg setation, trochanter to tarsus (including famulus): I (1-4-3-5-16); II (1-4-4-5-11); III (2-3-3-3-10); IV (2-3-3-3-10); formula of solenidia, genu to tarsus: I (2-1-3); II (1-1-2); III (1-1-0); IV (1-1-0). Solenidion $\varphi_{2}$ of tibia I not evident. Setae $v$ " of tibia III, $p v$ ' and $a$ of tarsus III, $v$ " of tibia IV and $p v$ " and $a$ of tarsus IV strongly modified, expanded distally (spatula-shaped). Setation of legs I-IV as shown in Figs. 18, 19, $21 \& 22$.

Material examined. Two specimens (holotype and paratype, females): Mt. Oboshi, Mineson, Tsushima Islands, 18-X-1968; one specimen (paratype, female): Mt. Okora, Gaya, Shimoagata-gun, Tsushima Islands, Japan, 22-X-1968, Leg. J. Aoki.

Remarks. I observed only one pair of lyrifissure $i h$ on the notogaster, four pairs ( $i a, i m$, ih and $i p$ ) are shown in the original description. In the original description, only 9 setae were illustrated on tarsus IV, but I noted 10 setae including seta $f t$ ". Leg setae $v$ " of tibia III, $p v$ " and $a$ of tarsus III, $v$ " of tibia IV and $p v$ " and $a$ of tarsus IV are strongly modified (spatula-shaped). This species is unique among previously known species of Epilohmannia in having the above mentioned spatula-shaped setae on tibiae and tarsi III and IV.

Distribution. Japan: Tsushima Isl., Hokkaido, Fukushima, Tochigi Prefectures, Himeshima Isl. (Aoki 1970; Fujikawa 1972; Kubota 1987; Fujikawa et al. 1993), China (Wang et al. 1992; Aoki et al. 1997) and Korea (Choi 1997).

\section{Epilohmannia spathuloides sp. nov. (Figs. 23-29)}

Measurements. Body length 826.8-864.4 (845.6) $\mu \mathrm{m}$; width of hysterosoma 343.6-357.0 (350.3) $\mu \mathrm{m}$; length of proterosoma 286.9-294.9 (290.9) $\mu \mathrm{m}$; width of proterosoma 215.8-224.4 (220.1) $\mu \mathrm{m}$; length of hysterosoma 589.6-600.0 (594.8) $\mu \mathrm{m}$.

Integument. colour deep reddish-brown to dark brown; rostral part of prodorsum and legs yellowish brown. Cerotegument very thick, whole dorsal and ventral plates as well as surface of legs densely covered by punctate. Exobothridial and lateral regions of prodorsum with a number of muscle sigillae.

Prodorsum. In dorsal aspect roughly elongate triangular in shape. Anterior margin of rostrum rounded, with a number of longitudinal striations anteriorly and laterally. Rostral setae (ro) relatively short, 36.4-41.6 (39.0) $\mu \mathrm{m}$, reaching to the tip of rostrum, situated very close to each other, and inserted at the same level, conspicuously barbed. Lamellar setae (le) long, about 61.3-65.0 (63.6) $\mu \mathrm{m}$, conspicuously barbed. Distance between bases of setae le-le a little longer than setal length. Interlamellar setae (in) very long, 174.2-182.0 (178.1) $\mu \mathrm{m}$, distinctly barbed, situated close and medial to each bothridium. Anterior exobothridial setae (exa) short, 23.4-31.2 (27.3) $\mu \mathrm{m}$, but well visible; posterior exobothridial setae (exp) very short 7-9.6 $\mu \mathrm{m}$, hardly visible. Sensillus (ss) long, 114.4-117.0 
(115.7) $\mu \mathrm{m}$, with long smooth stalk and narrow fusiform head bearing distinct barbs. Bothridium (bo) relatively small. A few muscle sigillae present medial to each bothridium (Fig. 23).
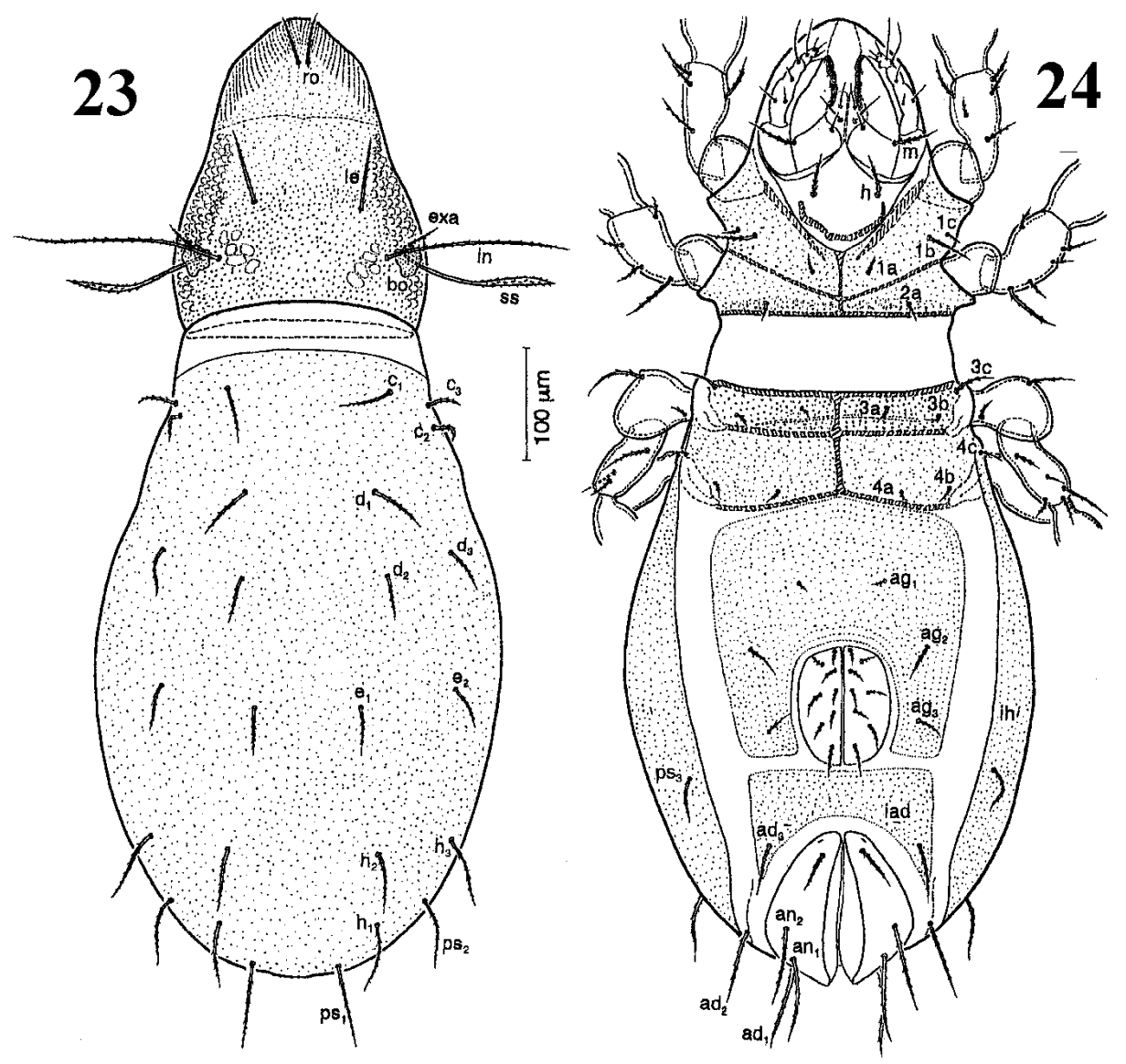

FIGURES 23-24. Epilohmannia spathuloides sp. nov. 23, dorsal aspect; 24, ventral aspect.

Notogaster. Elongate oval in shape, slightly wider posteriorly, its anterior margin slightly arched, posterior margin broadly rounded. Very robust in lateral view, dorso-ventral thickness of hysterosoma in postgenital transects about 214-219 $\mu \mathrm{m}$. Notogastral setae rather thick, conspicuously barbed; setae $p s_{1}$ longest, about twice as long as $e_{1}$, setae $p s_{3}, c_{2}$ and $c_{3}$ shortest, subequal in length. Latero-opistosomal gland opening $(\mathrm{gla})$ inconspicuous. Only lyrifissure $i h$ visible, other lyrifissures not evident (Fig.23).

Gnathosoma. Two pairs of thick and barbed setae $h$ and $m$, one pair of short and smooth hypostomal setae $a$ present (Fig. 24). Chelicerae robust, digits with four sclerotized teeth. Seta cha minute, $c h b$ long, thick. Palp three segmented, trochanter very large, without seta. Femur, genu and tibia fused together, with four smooth setae. Tarsus with a very thick solenidion $\omega$ and six setae; sul shorter and thinner than the other eupathidia.

Epimeral region. Apodemes apo.1, apo.2, apo.sj, apo.3 and apo.4 well developed. Each epimeral region divided into two parts by a sternal apodeme. Apodemes apo.1 convergent, forming a Vshape, but not fused medially and widely separated from each other. Apodemes apo.2, apo.sj, apo.3 
and apo.4 relatively long, completely fused medially. Epimeral setae medium short, subequal in length, except setae $1 b$ and $3 c$ about twice longer than other setae, all setae distinctly barbed (Fig. 24). Discidium poorly developed, relatively short. Accetabulae I and II situated close to each other.

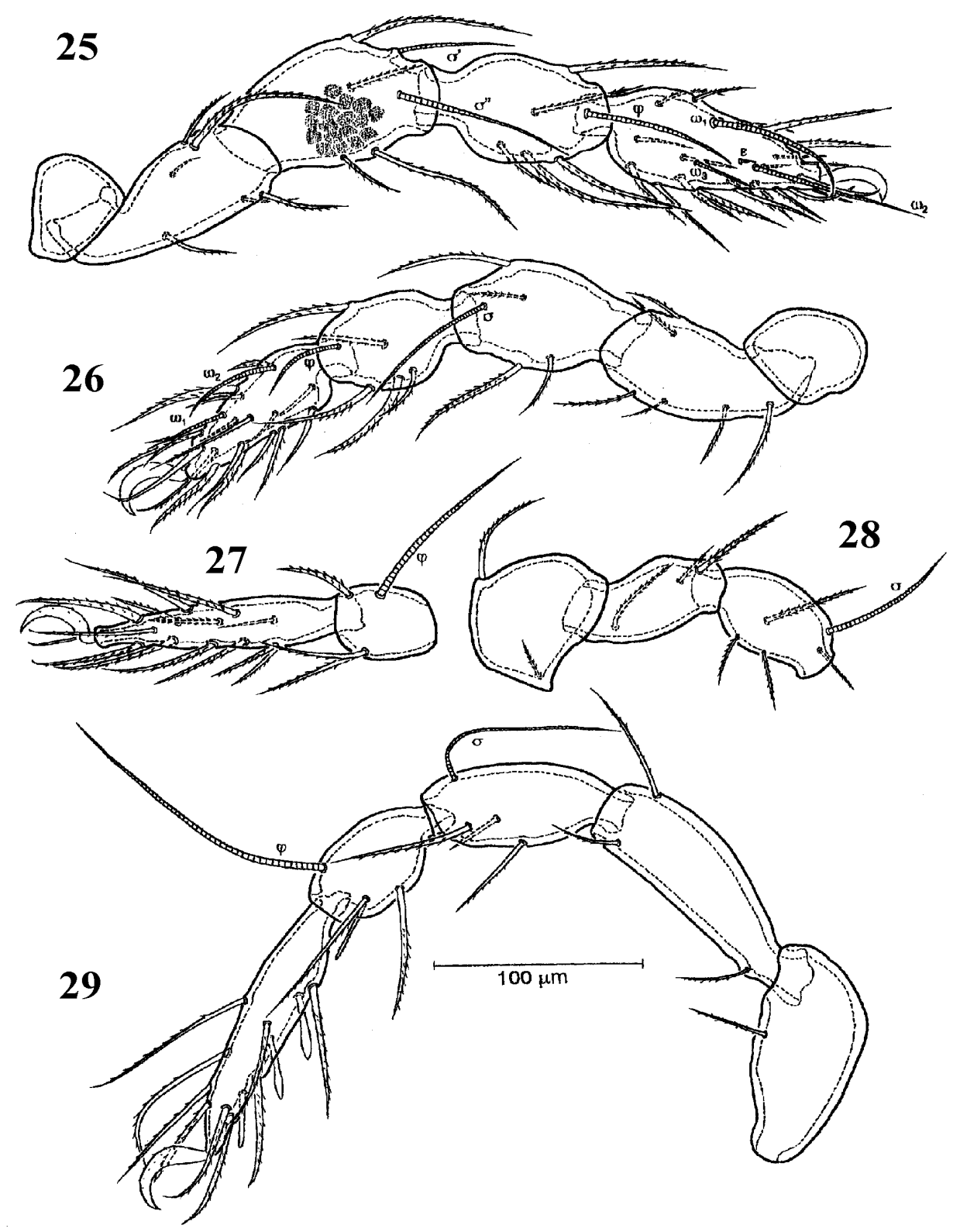

FIGURES 25-29. Epilohmannia spathuloides sp. nov. 25, leg I (right, antiaxial aspect); 26, leg II (left, antiaxial aspect); 27, tibia and tarsus III (right, antiaxial aspect); 28, trochanter, femur and genu III (left, antiaxial aspect); 29, leg IV (right, paraxial aspect).

Ano-genital region. Genital aperture rounded rectangular, anal aperture narrowed anteriorly and strongly widened posteriorly, the latter aperture distinctly larger than the former. Each genital plate 
with five setae along its median margin and three setae inserted laterally. Aggenital seta $a g_{1}$ much shorter than the other setae. All genital and aggenital setae distinctly barbed. Anal setae long, much longer than genital setae. Anal lyrifissures ian located near the anterolateral corner of each anal plate, and obliquely oriented with respect to the body axis. Adanal setae long, distinctly barbed, posterior two pairs longer than the anterior pair. Adanal lyrifissures iad similar in shape to ian, situated almost transversely adjacent to the anterolateral margin of anal aperture. Adanal plate narrowing posteriorly around anal aperture and incomplete posterior to anal region (Fig. 24).

Legs. Claws strongly thickened, dorsal surface of each claw with few serrations. Tarsi I and II stronger, but shorter than those of the other legs; tibiae and genua III and IV more slender than those of legs I and II. Femur IV and trochanter IV much longer than those of the other legs. Formula of leg setation, trochanter to tarsus (including famulus): I (0-6-4-5-22); II (0-6-4-5-18); III (2-3-4-3-14); IV (1-3-3-3-12); formula of solenidia, genu to tarsus: I (2-1-3); II (1-1-2); III (1-1-0); IV (1-1-0). Solenidion $\omega_{1}$ of tarsus I strongly curved, while $\omega_{2}$ nearly straight, almost same in length; $\omega_{3}$ short and thin. Famulus $\varepsilon$ very small, situated behind solenidion $\omega_{2}$. Solenidion $\varphi$ of tibia I almost as long as $\omega_{l}$ of tarsus I. Solenidion $\sigma$ of genu I short, thin, $\sigma$ " nearly as long as $\varphi$ of tibia I. Setae $a$ " and $p v$ " of tarsus IV strongly modified, not thickened proximally, but expanded distally (spatula-shaped). Setae $s$ of tarsus IV and $l$ " of tibia IV slightly modified, isodiametric and blunt distally. Other setae of legs normally developed and conspicuously barbed. Setation of legs I-IV as shown in Figs. 25-29.

Variations. No variation was observed in examined characters.

Material examined. Holotype (female) and a paratype (female): from litter of larch plantation (Larix kaempferi), Tennyosan, Mt. Yatsugatake, Yamanashi Prefecture, Japan, $36^{\circ} 56^{\prime} \mathrm{N}, 138^{\circ} 25^{\prime}$ E, 1520 m, 5-XI-1999, Leg. B. Bayartogtokh. Both specimens are deposited (in alcohol) in the Acarology collection of the National Science Museum, Tokyo.

Remarks. Among previously described species of Epilohmannia, only E. spathulata Aoki, 1970 and E. spathuloides sp. nov. have spatula-shaped setae on some leg segments. However, Epilohmannia spathuloides is easily distinguishable from $E$. spathulata by 1$)$ the much larger body size ( $E$. spathulata 520-550 $\mu \mathrm{m}$ in length; $230-250 \mu \mathrm{m}$ in width); 2) the thick and conspicuously barbed notogastral, epimeral and ano-genital setae as opposed to thin and smooth setae in E. spathulata; 3 ) the rounded rectangular shape of genital aperture as opposed to elongate oval aperture in E. spathulata; 4) the heterogeneity of aggenital setae (in the new species $a g_{1}$ is much shorter than $a g_{2}$ and $a g_{3}$, while all aggenital setae are subequal in length in E. spathulata); 5) the different number of setae on trochanters I, II and IV, femora I and II, genua I and III, and tarsi I-IV; 6) the presence of spatulashaped setae, developed only on tarsus IV, while E. spathulata bears such setae on both the tarsi and tibiae of legs III and IV; 7) the presence of distinct punctation on body surface and 8) the difference in body colour. In addition, this species is unique among the known species of Epilohmannia in the number of setae (neotrichy) on tarsi I-IV and femora I and II.

Etymology. The specific epithet "spathuloides" refers to the presence of spatula-shaped setae on the tarsus IV, which are similar to those of E. spathulata Aoki.

\section{Epilohmannia shtanchaevae sp. nov. (Figs. 30-36)}

Measurements. Body length 601.8-617.1 (609.4) $\mu \mathrm{m}$; width of hysterosoma 244.8-265.2 (255.3) $\mu \mathrm{m}$; length of proterosoma 193.8-219.3 (207.4) $\mu \mathrm{m}$; width of proterosoma 145.3-147.9 (146.6) $\mu \mathrm{m}$; length of hysterosoma 392.7-408 (401.2) $\mu \mathrm{m}$.

Integument. colour of body yellowish-brown; rostral part of prodorsum and legs light-yellowish brown. Cerotegument rather thick, dorsal surface nearly smooth, only exobothridial region and marginal part of notogaster granulated. Ventral plate, anal and genital plates and as well as surface of legs densely covered by relatively small granules. 

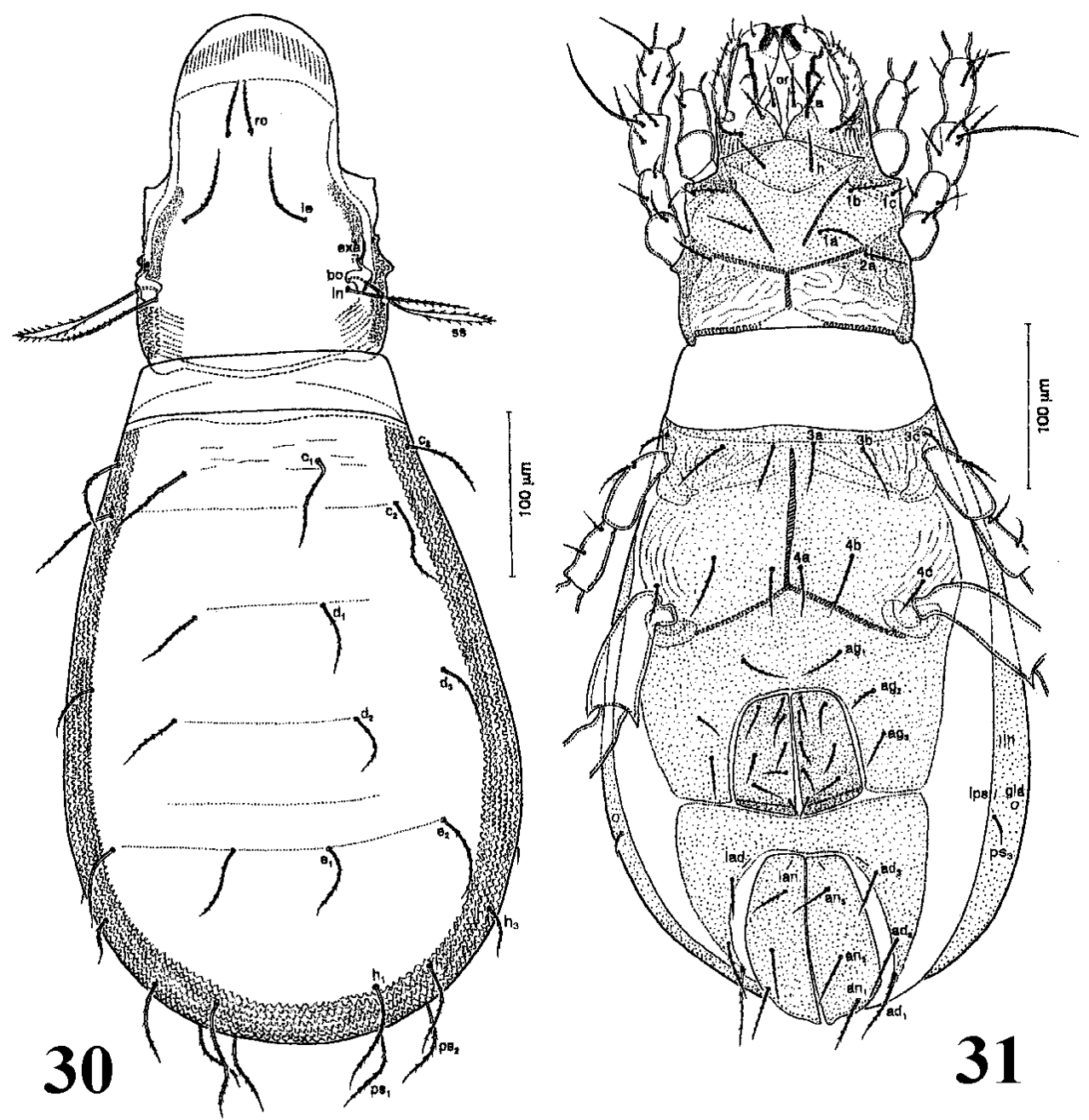

FIGURES 30-31. Epilohmannia shtanchaevae sp. nov. 30, dorsal aspect; 31, ventral aspect.

Prodorsum. Rostrum strongly elongated, with a very broadly rounded anterior margin. Weakly developed longitudinal striations along the anterior and lateral margins of rostrum. Rostral setae (ro) long, 28.6-31.2 (29.9) $\mu \mathrm{m}$, about twice as long as distance between their bases, conspicuously barbed. Insertions of rostral setae symmetrical and far removed from the anterior margin of rostrum. Lamellar setae (le) long, 57.2-59.8 (58.5) $\mu \mathrm{m}$, conspicuously barbed. Distance between bases of setae le-le slightly longer than setal length. Interlamellar setae (in) long, 72.8-83.2 (76.3) $\mu \mathrm{m}$, but shorter than sensilli, barbed, situated close to and posteromedially of each bothridia. Anterior exobothridial setae (exa) short, 23.4-36.4 (29.9) $\mu \mathrm{m}$, situated anterior to each bothridium, finely barbed. Posterior exobothridial setae (exp) very small, 7.8-10.4 (9.1) $\mu \mathrm{m}$, smooth, poorly observable, situated lateral to each bothridium. Sensillus (ss) long, 78-98.8 (84.9) $\mu \mathrm{m}$, with long, but narrow stalk and fusiform head bearing relatively long barbs. Bothridium (bo) small. A few oblique striations present posterior to each bothridium (Fig. 30). 

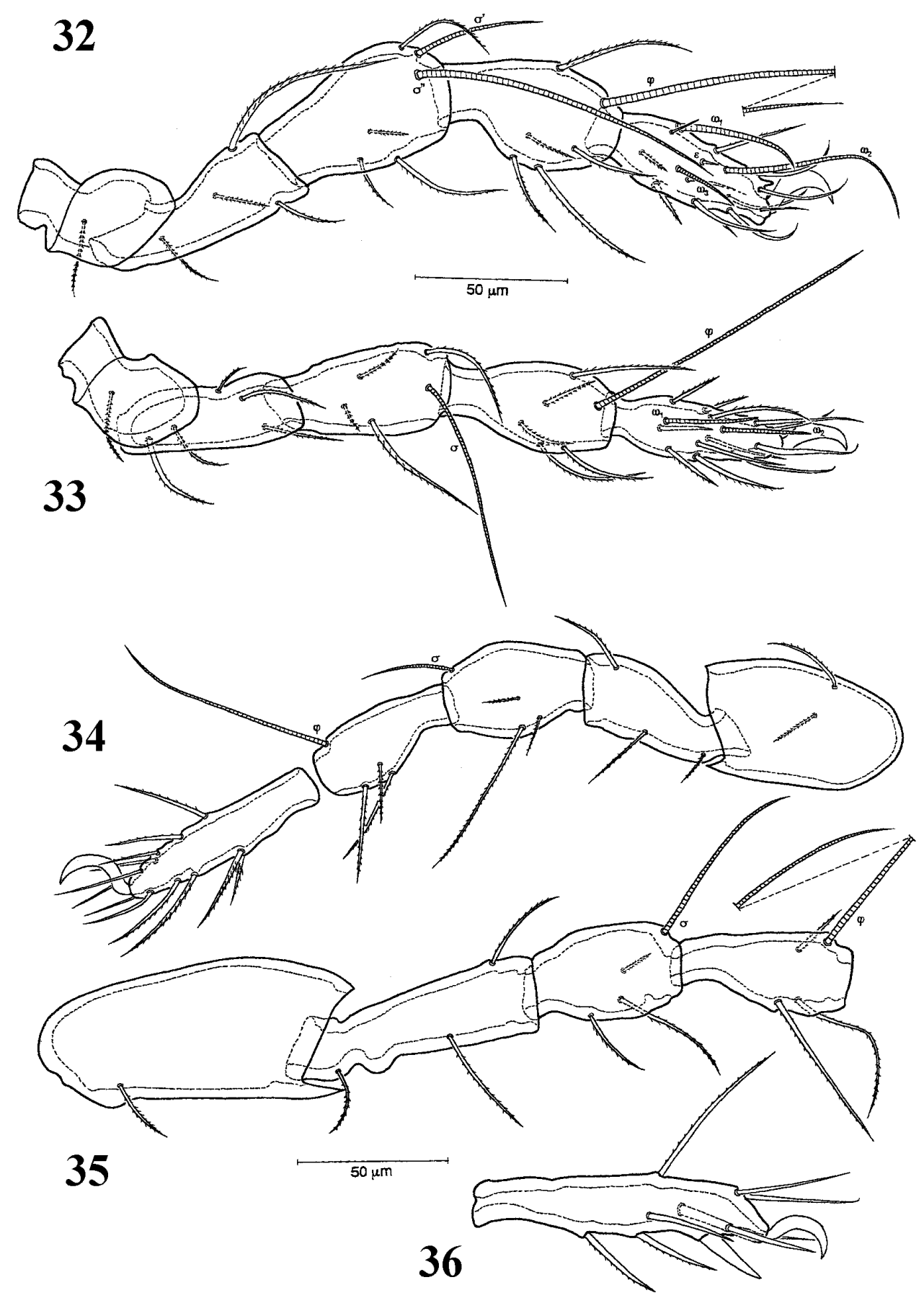

FIGURES 32-36. Epilohmannia shtanchaevae sp. nov. 32, leg I (right, antiaxial aspect); 33, leg II (right, antiaxial aspect); 34, leg III (right, paraxial aspect); 35, trochanter, femur, genu and tibia IV (left, paraxial aspect); 36, tarsus IV (left, paraxial aspect). 
Notogaster. Elongate oval in shape, distinctly wider posteriorly than anteriorly, its anterior margin almost straight and posterior margin broadly rounded. Robust in lateral view, dorso-ventral thickness of hysterosoma in postgenital transect 181-187 $\mu \mathrm{m}$. Notogastral setae, except proximal part, conspicuously barbed; setae $h_{1}, h_{2}, p s_{1}$ and $p s_{2}$ longest, slightly longer than other setae, seta $p s_{3}$ shortest, about $1 / 4$ as long as $h_{l}$. Latero-opistosomal gland opening ( $g l a$ ) rather large, situated close to setae $p s_{3}$. Only two pairs of lyrifissures, ih and ips well developed, other lyrifissures not evident. Lateral and posterior margins of notogaster with dense sigillae, appearing as undulating striations (Fig. 30).

Gnathosoma. Hypostomal setae $a, h$ and $m$ long, distinctly barbed (Fig. 31). Chelicerae robust, digits with four sclerotized teeth. Seta $c h a$ minute, $c h b$ long, thick, smooth. Palp three-segmented, trochanter very small, without seta. Structure and setation of palp normal for genus.

Epimeral region. Apodemes apo.1, apo.2, apo.sj and apo. 4 well developed, while, apo. 3 poorly developed and represented by inconspicuous line. Epimeral regions between apo.2 and apo.sj, and between apo. 3 and apo. 4 divided into two parts by a sternal apodeme. Apodemes apo. 1 convergent, forming V-shaped, but not fused medially and widely separated from each other. Apodemes apo.2 fused medially to each other; apo.sj and apo. 3 not fused, while apo.4 fused medially. Epimeral setae relatively long, subequal in length, other than short $1 c$ and $3 c$; all setae distinctly barbed (Fig. 31). Discidium inconspicuously developed. Acetabula I and II situated close to each other, while acetabula III and IV situated far from each other.

Ano-genital region. Genital aperture nearly quadrangular, anal apertures nearly rounded oval, a little larger than the genital aperture. Each genital plate with five setae along its median margin and three setae inserted laterally. Posterior pair of genital setae a little shorter than the other setae. All genital and aggenital setae conspicuously barbed. Anal setae slightly longer than genital setae. Anal lyrifissures ian located near the anteromedian corner of each anal plate, and obliquely oriented with respect to the body axis. Posterior two pairs of adanal setae slightly longer than anterior pair. Adanal lyrifissures iad slightly longer than ian, situated adjacent to the anterolateral margin of anal aperture (Fig. 31). Adanal plate narrowing posteriorly around anal aperture and incomplete posterior to anal region.

Legs. Claws strongly thickened, dorsal surface smooth. Dorsodistal part of tarsus I with distinct projection; trochanters III and IV with strong ventrodistal and slight dorsodistal projections. Tarsi I and II thicker and shorter than those of the other legs. Femur and trochanter IV much longer than those of the other legs. Formula of leg setation, trochanter to tarsus (including famulus): I (1-4-4-513); II (1-5-4-5-12); III (2-3-3-3-12); IV (1-3-3-3-10); formula of solenidia, genu to tarsus: I (2-13); II (1-1-2); III (1-1-0); IV (1-1-0). Setae $a$ and $s$ of tarsus IV very thick. Setation of legs I-IV as shown in Figs. 32-36.

Variations. No significant variation in described character states was observed. Only the arrangement of some epimeral setae was slightly variable, i.e. in one specimen, setae $4 a$ and $4 b$ were situated asymmetrically.

Material examined. Holotype (female) and nine paratypes (females): from soils of $30-40 \mathrm{~cm}$ in depth, Mt. Khustai, Altanbulag District, Central Province, Mongolia, mountain-steppe (Stipa grandis + Cleistogenes squarosa), $47^{\circ} 42^{\prime} \mathrm{N}, 106^{\circ} 25^{\prime} \mathrm{E}, 1640 \mathrm{~m}, 10$ October, 1996. Leg. B. Bayartogtokh. The holotype and five paratypes are (all specimens in alcohol) deposited in the Acarology collection of the Department of Zoology, National University of Mongolia, Ulaanbaatar, and two paratypes in the Acarology collection of the National Science Museum, Tokyo and two paratypes in the collection of Field Museum of Natural History, Chicago.

Remarks. The new species can readily be distinguished from most other known species of Epilohmannia by the very broadly rounded shape of the rostrum, the posteriorly widened shape of the notogaster with many marginally located sigillae. In spite of the above characters, the following 
known species, E. cylindrica (Berlese), E. gigantea Berlese, E. imreorum Bayoumi et Mahunka and E. pallida Wallwork resemble the new species in some general respects. However, Epilohmannia shtanchaevae is easily distinguishable from E. cylindrica not only by the shape and sigillae of rostrum and notogaster, but also by the relatively long epimeral and ano-genital setae, the rostral setae situated far posterior from the anterior margin of rostrum, the different structure and number of setae on tarsi I-IV, tibia I, femur II and trochanter IV, respectively, and the larger body size. Two other species, E. gigantea and E. imreorum differ from the present new species in the different size of notogastral setae (setae $c_{3}$ and $p s_{3}$ in these two species very short and smooth, much shorter than in the new species and other setae longer and thicker than those of the present species), the presence of strongly modified and thick setae $p v^{\prime}, p v^{\prime}$ " on tarsi IV, $v^{\prime}, v^{\prime}$, and $l$ ” on tibiae IV and $v^{\prime}$ genua IV (these setae are normally developed in the new species). Another nominal species, E. pallida and its subspecies differs from the new species in the relatively short notogastral setae, the different number of setae of tarsi I-IV, and dissimilar structure of setae of tarsus IV.

Etymology. This species is named in honor of the Russian acarologist, Dr. U. Ya. Shtanchaeva, Caspian Institute of Biological Resources, Russian Academy of Sciences, who completed a recent review of Epilohmanniidae.

\section{Discussion}

As I mention above, the taxonomy of the family Epilohmanniidae is somewhat difficult because of the lack of complete descriptions and diagnosis as well as detailed illustrations for many known species. Only the representatives of Epilohmannoides and Neoepilohmannia are easily recognizable, and both genera consist of relatively few species. Moreover, most species of these two genera have been described or redescribed recently.

In contrast, many species of the type-genus, Epilohmannia, which were described in the past, have insufficient information on their taxonomy. The descriptions of those species are based mostly on very few characters, showing only the structure of dorsal and/or ventral aspects and setation of tarsus IV, and the structure and setation of other legs, important for the definition of Epilohmannia species, were neglected. Therefore, it is very difficult, without examining type material, to produce the complete diagnoses and identification key to all known Epilohmannia species of the world. Thus, in this study, I limit the identification key to Japanese and Mongolian epilohmanniid species, on which enough material and information and recent identifications are available.

\section{Key to the Japanese and Mongolian species of Epilohmanniidae}

1. Aggenital neotrichy present; sixteen pairs of aggenital setae $\ldots \ldots \ldots \ldots \ldots \ldots \ldots \ldots$ $\ldots \ldots \ldots \ldots \ldots \ldots \ldots \ldots \ldots \ldots \ldots \ldots \ldots \ldots \ldots \ldots$ Neopilohmannia ovata (Aoki, 1961)

Aggenital neotrichy absent, e.g. only two or three pairs of aggenital setae $\ldots \ldots \ldots \ldots 2$

2. Ventral plate complete, not divided; only two pairs of aggenital setae; rostrum strongly protruding in the middle with a pointed tip.......... Epilohmannoides esulcatus Ohkubo, 1979

- Ventral plate transversely divided into two parts; three pairs of aggenital setae; rostrum rounded

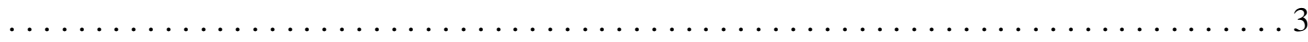

3. Tarsus IV with thickened, but not spatulate setae; interlamellar setae shorter than sensilli ... 4

- Tarsus IV with two spatulate setae ( $a$ ” and $p v$ ”), which are expanded distally; interlamellar setae

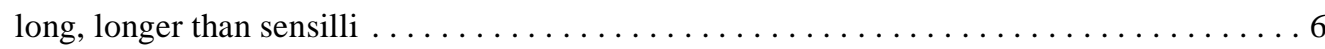


4. Tarsus IV with 9 setae; at least three setae of tarsus IV strongly thickened; rostrum rounded, but somewhat narrowed anteriorly; epimeral and ano-genital setae relatively short. . . . . . 5

- Tarsus IV with 10 setae; only two setae of tarsus IV ( $a$ and $s$ ) strongly thickened; rostrum broadly rounded; epimeral, genital and aggenital setae long

. E. shtanchaevae sp. nov. (Figs. 30-36)

5. Notogaster long, more than twice as long as prodorsum; dorsal and ventral surfaces of body densely granulated; setae $a, s$ and $t c$ ' of tarsus IV thickened, sometimes seta $u$ ' also thickened, setae $f t ", p v "$ not thickened, but normally developed

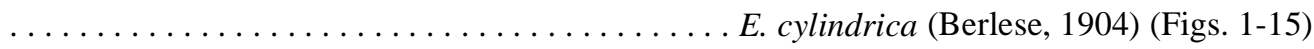

- Notogaster relatively short, about $1.5 \mathrm{x}$ as long as prodorsum; dorsal surface of body nearly smooth, only ventral plate granulated; setae $p v$ ", $f t^{\prime}, a$ and $s$ of tarsus IV thickened; setae $t c$ ', $u$ ' normally developed ..................... pallida pacifica Aoki, 1965

6. Relatively small species (body length 520-550 $\mu \mathrm{m}$; width $230-250 \mu \mathrm{m}$ ), notogastral and ventral setae thin, smooth; genital aperture elongate oval, all aggenital setae subequal in length; tarsi III and IV, tibiae III and IV with spatula-shaped setae . . . . . . . . . . . . . . . . . . . . . . . . . . . . . . E Eilohmannia spathulata Aoki, 1970 (Figs. 16-22)

- $\quad$ Very large species (body length 827-864 $\mu \mathrm{m}$; width 343-357 $\mu \mathrm{m}$ ); notogastral and ventral setae thick, distinctly barbed; genital aperture rectangular oval; aggenital seta $a g_{1}$ shorter than others; only tarsus IV with spatula-shaped setae. . Epilohmannia spathuloides sp. nov. (Figs. 23-29)

\section{Acknowledgements}

I would like to express my heartfelt thanks to Prof. Jun-ichi Aoki, Yokohama National University, Yokohama, Japan and to the anonymous reviewers for their critically reading the manuscript with many useful comments. Thanks are also due to Dr. N. Kaneko, Yokohama National University, Yokohama, Japan, for his help during field studies and material collections in Mt. Yatsugatake. This study was supported by the Japan Society for the Promotion of Science.

\section{References}

Aoki, J. (1961) Beschreibungen von neuen Oribatiden Japans. Japanese Journal of Applied Entomology \& Zoology, 5(1), 64-69.

Aoki, J. (1965) Notes on the species of the genus Epilohmannia from the Hawaiian Islands (Acarina: Oribatei). Pacific Insects, 7(2), 309-315.

Aoki, J. (1970) The oribatid mites of the Islands of Tsushima. Bulletin of the National Science Museum Tokyo, 13(3), 395-442.

Aoki, J., Yamamoto, Y., Wen, Z., Wang, H. \& Hu, S. (1997) A checklist of oribatid mites of China (Acari: Oribatida). First report. Bulletin of the Institute of Environmental Science and Technology, Yokohama National University, 23(1), 63-80.

Ayyildiz, N. \& Özkan, M. (1988) Erzum ovasi oríbatíd akarlari (Acari: Oribatida) Üzeríne sístematík arastirmalar. I. Ílkel Oríbatídler. Doga, 12(2), 115-130.

Balogh, J. (1943) Magyarorszag Páncélosatkái (Conspectus oribateorum Hungariae). A Magyar Tudományos Akadémia Kiadása, Budapest. 202 pp.

Balogh, J. \& Balogh, P. (1992) The Oribatid Mites Genera of the World. Vol. 1. Hungarian National Museum Press, Budapest. 263 pp.

Balogh, J. \& Mahunka, S. (1983) Primitive Oribatid Mites of the Palaearctic Region. Académia Kiada, Budapest. $372 \mathrm{pp}$. 
Bayoumi, B. M. \& Mahunka, S. (1976) Contributions to the knowledge of the genus Epilohmannia Berlese, 1916 (Acari: Oribatida). Folia Entomologica Hungarica, 29(1), 5-21.

Behan-Pelletier, V. M. (1993) Diversity of soil arthropods in Canada: Systematic and ecological problems. Memoirs of the Entomological Society of Canada, 165, 11-50.

Berlese, A. (1904) Acari nuovi. Manupulus III. Redia, 2, 10-32, pls. 1 \& 2.

Berlese, A. (1916) Centuria seconda di Acari nuovi. Redia, 12, 125-177.

Bhaduri, A. K. \& Raychaudhuri, D. N. (1981) Taxonomy and distribution of oribatid mites (Acari) in India. Insecta Matsumurana, 23, 21-39.

Bolen, E. G., \& McDaniel, B. (1989) Neoepilohmannia, a new genus of the family Epilohmanniidae (Oribatida: Epilohmannoidea). International Journal of Acarology, 15(2), 103-106.

Bulanova-Zachvatkina, E. M. (1967) Oribatid Mites. "Vysshaya shkola", Moscow. 255 pp. [in Russian].

Bulanova-Zachvatkina, E. M. (1975) Family Epilohmanniidae. In: Gilyarov, M. S. \& Krivolutsky, D. A. (eds.) A Key to the Soil-inhabiting Mites. Sarcoptiformes. "Nauka", Moscow. p. 70-71. [in Russian].

Choi, S. (1997) Checklist of oribatid mites (Acari: Oribatida) of Korea. Korean Arachnology, 13(1), 83-104. [in Korean, with English abstract].

Fujikawa, T. (1972) A contribution to the knowledge of the oribatid fauna of Hokkaido (Acari: Oribatei). Insecta Matsumurana, 35, 127-183.

Fujikawa, T., Fujita, M. \& Aoki, J. (1993) Checklist of oribatid mites of Japan (Acari: Oribatida). Journal of the Acarological Society of Japan, 2(1), 1-121. [in Japanese].

Grandjean, F. (1946) Au sujet de l'organe de Claparède, des eupathidies multiples et des taenidies mandibulaires chez les Acariens actinochitineux. Archive des Sciences Physiques et Naturelles Genève 5(28), 6387.

Hammen, L.Van Der, (1959) Berlese's Primitive Oribatid Mites. Zoologische Verhandelingen, 40, 1-93.

Jacot, A. P. (1934) Some Hawaiian Oribatoidea (Acarina). Bernice P. Bishop Museum Bulletin, 121, 1-99, pls. 1-16.

Karppinen, E., Krivolutsky, D. A. \& Poltavskaya, M. P. (1986) List of oribatid mites (Acarina: Oribatei) of northern Palaearctic region. III. Arid lands. Annales Entomologici Fennici, 52, 81-94.

Karppinen, E., Krivolutsky, D. A., Tarba, Z. M., Shtanchaeva, U. Ya. \& Gordeeva, E. W. (1987) List of oribatid mites (Acarina, Oribatei) of northern Palaearctic region. IV. Caucasus and Crimea. Annales Entomologici Fennici, 53, 119-137.

Karppinen, E., Melamud, V. V., Miko, L. \& Krivolutsky, D. A. (1992) Further information on the oribatid fauna (Acarina, Oribatei) of northern Palaearctic region: Ukraine and Czechoslovakia. Entomologica Fennnica, 3, 41-56.

Krivolutsky, D. A. (1995) The Oribatid Mites.Naukaî, Moscow. 224 pp. [In Russian, with English summary].

Kubota, T. (1987) Oribatid mite communities in Himeshima Island, Fukuoka Prefecture. Biologia Fukuoka, 27, 9-16. [in Japanse].

Lombardini, G. (1936) Elenco alfabetico di specie esistenti nell'acaroteca della R. Stazione di Entomologia Agraria di Firenze. Redia, 22, 37-51.

Mahunka, S. (1980) Data to the knowledge of mites preserved in the "Berlese Collection" (Acari: Tarsonemina, Oribatida). II. Folia Entomologica Hungarica, 61(1), 105-121.

Marshall, V. G., Reeves, R. M. \& Norton, R. A. (1987) Catalogue of the Oribatida (Acari) of Continental United States and Canada. Memoirs of the Entomological Society of Canada, 39, 1-418.

Niedbala, W. \& Olszanowski, Z. (1997) Acari-Roztocze. In: Razowski, J. (ed.) Checklist of animals of Poland, Vol. IV, p. 247-259.

Norton, R. A., Metz, L. J. \& Sharma, G. D. (1978) Observations on Epilohmannoides Jacot, 1936 (Acarina: Oribatei), with the description of a new species. Journal of the Georgia Entomological Society, 13(2), 134148.

Ohkubo, N. (1979) A new species of the genus Epilohmannoides (Acarina, Oribatida) from Japan. Annotationes Zoologicae Japonenses, 52(4), 261-265.

Oudemans, A. C. (1917) Notizen über Acari, 25. Reihe (Trombidiidae, Oribatidae, Phthiracaridae). Archiv fur Naturgeschichte, 82, 1-84. 
Oudemans, A.C. (1923) Studie over de sedert 1877 ontworpen systemem der Acari; nieuwe classificatie; phylogenetische beschouwingen. Tijdschrift voor Entomologie, 66: 49-85.

Pérez-Iñigo, C. (1968) Ácaros oribátidos de Suelos de España Peninsular e Islas Baleares (1. a parte) (Acari, Oribatei). Graellsia, 24, 143-238.

Pérez-Iñigo, C. \& Baggio, D. (1985) Oribates édaphiques du Brésil (II). Oribates de Líile du "Cardoso" (Premiére partie). Acarologia, 26(2), 183-199.

Prasad, V. (1974) A catalogue of mites of India. Indira Acarology Publishing House, Lidhiana (Pinjab). 320 pp.

Schatz, H., 1998. Oribatid mites of the Galápagos Islands - faunistics, ecology and speciation. Experimental \& Applied Acarology, 22, 373-409.

Schuster, R. (1960) Über die Morphologie und Artengliederung der Gattung Epilohmannia Berlese, 1917 (Ac., Oribatei). Zoologischer Anzeiger, 165(5/6), 197-213.

Sheals, J. G. (1965) Primitive Cryptostigmatid mites from Rhododendron forests in the Nepal Himalaya. Bulletin of the British Museum (Natural History) Zoology, 13(1), 1-35.

Shtanchaeva, U. Ya. (1996) Oribatid mites of the family Epilohmanniidae (Oribatida) of the world. Zoologicheskii Zhurnal, 75(4), 516-532. [in Russian, with English summary].

Shtanchaeva, U. Ya. \& Koshanova, R. E. (1987) Variation of an oribatid mite, Epilohmannia cylindrica Berlese, 1904 in its distribution area. Vestnik Karakalpakskogo Filiala Academii Nauk USSR, 109(3), 30-34. [in Russian].

Swift, S. F. \& Norton, R. A. (1998) Preliminary Report on Oribatid Mite (Acari: Oribatida) Diversity in the Hawaiian Islands. Bishop Museum Occasional Papers, 57, 1-44.

Wallwork, J. A. (1964) Some Oribatei (Acari: Cryptostigmata) from Tchad ( $1^{\text {st }}$ series). Revue de Zoologie et de Botanique Africaines, 70(3-4), 353-385.

Wang, H., Hu, S., Wang, X. \& Cui, Y. (1992) Acari: Oribatida. In: Insects of Wuling Mountains Area, Southwestern China, 701-711. [in Chinese, with English summary].

Accepted: 28 April 2000 